\title{
Between Coronavirus and COVID-19: Influence of Nigerian Newspapers' Headline Construction on Audience Information- Seeking Behaviour
}

\author{
Babatunde Raphael OJEBUYI ${ }^{1}$, Mutiu Iyanda LASISI ${ }^{2}$, Umar \\ Olansile AJETUNMOBI ${ }^{3}$
}

\begin{abstract}
Since the onset of the new coronavirus, the mass media, across the globe, have continued to draw special attention to the disease by adopting different pragmatic and rhetoric strategies. In Nigeria for instance, the news media have continued to draw people's attention to the virus by using COVID-19 and coronavirus as synonymous lexical entities in the headlines of their news stories. These lexical choices are believed to have some influence on how the audience understand and seek information about the virus. However, existing studies in media and health communication have not copiously explored the relationship between the lexical choices by media to report the COVID-19 pandemic and people's information-seeking behaviour about the virus. This study was, therefore,

\footnotetext{
${ }^{1}$ Department of Communication and Language Arts, University of Ibadan, Nigeria ojebabson@gmail.com; ojebuyi.raphael@dlc.ui.edu.ng https://orcid.org/0000-0002-1383-7630

${ }^{2}$ Infoprations Limited, Nigeria mutiu.iyanda@gmail.com https://orcid.org/0000-0003-0022-711X

${ }^{3}$ Infoprations Limited, Nigeria ajetunmobiumarolansile@gmail.com https://orcid.org/0000-0002-3670-5251

DOI: 10.17932/EJOSS.2021.023/ejoss_v01i1005
} 
designed to investigate how Nigerian journalists used coronavirus and COVID-19 as the key terms to report the virus and how the pragmasemantic implicatures of the lexical choices influenced audience information-seeking behaviours. Pragmatic Acts and Information-Seeking theories were employed as the theoretical framework while online survey and content analysis were adopted as methods. Findings show that although Nigerian journalists used coronavirus $(\mathrm{SD}=2.090)$ more often than COVID-19 (SD=1.924) in the headlines, the audience employed COVID-19 $(\mathrm{M}=2.23, \mathrm{SD}=.810)$ more than coronavirus $(\mathrm{M}=1.88$, $\mathrm{SD}=.783$ ) while searching information about the virus. Besides, journalists' use of COVID-19 in the headlines to educate (Chi-square $=37.615$, df=11, $\mathrm{P}<.000$ ), warn (Chi-square $=26.153$, $\mathrm{df}=11, \mathrm{P}<.006$ ), assess (Chi-square $=24.350, \mathrm{df}=11, \mathrm{P}<.011)$ and sensitise (Chi-square $=24.262, \mathrm{df}=11, \mathrm{P}<.012)$ facilitated audience interest in seeking information about the virus than when coronavirus is used as a keyword in the headlines. The lexical choices made by journalists to report a health crisis such as the COVID-19 pandemic have implications for citizens' knowledge about the crisis.

Keywords: Coronavirus, COVID-19, Lexical choices by Nigerian journalists, Pragma-semantic implicatures, Information-Seeking behaviour of news audience

\section{INTRODUCTION}

In late December 2019 when the first case of new Coronavirus was reported in Wuhan, China, scientists identified it as 2019-nCoV, standing 
for 'novel Coronavirus 2019.' Later, on February 11, 2020, the World Health Organisation (WHO) officially tagged it COVID-19 (Guarner, 2020 \& Berkeley, 2020). According to Berkeley, $C O$ refers to Corona, VI for Virus, $D$ for Disease (WHO, 2020) while 19 stands for the year the virus was first recorded in Wuhan. The World Health Organisation submits that the rationale for naming the novel virus as COVID-19 was to avoid racial discrimination, stigmatisation, unnecessary framing and public panic. Essentially, the organisation adopted the taxonomy as a risk communication strategy to control international crises that might arise from the virus that has infected and killed millions of people worldwide (Worldometer, 2021).

When the new virus began to ravage the world, the mass media in their global coverage immediately started to draw special attention to issues around COVID-19 (Colvin, 2020). In Nigeria for instance, it has been observed that the print media especially used 'COVID-19 and coronavirus in their headlines to draw people's attention to the pandemic. These two words - coronavirus and COVID-19 - have continued to keep appearing in the news headlines as if the two lexicons were synonymous. 'Coronaviruses are a large family of viruses which may cause illness in animals or humans' while 'COVID-19 is the infectious disease caused by the most recently discovered coronavirus' (WHO, 2020). It has been reported that COVID-19 is the 7th coronavirus family documented to have infected humans (Al-Jazeera, 2020). Thus, getting two different names for the novel virus in the media implies that the audiences are likely to select the name that resonates with their initial awareness. 
Just as argued by Dong and Zheng (2020), the mass media is a powerful information source people rely on during health crises. Besides, the presence of the news media online has further provided better platforms for citizens to participate in public debates about issues such as politics, health, security and national unity (Ojebuyi, 2016; Ojebuyi \& Lasisi, 2019). What the audience consume in the media determines, to a large extent, their perspectives about such issues raised by the media. As such, what guides people to news stories (such as headlines) must be crafted in a manner that does not confuse the mass audience or alter reality (Dong \& Zheng, 2020). Given the fact that two different names-coronavirus and COVID-19-are constantly used to cast headlines in Nigerian newspapers, there is the need to investigate how interpretations of the two terms (coronavirus and COVID-19) could influence Nigerians while searching for news about the virus. This is the primary focus of this study.

\section{STATEMENT OF THE PROBLEM}

Evidence from literature shows that scholars have conducted some empirical studies on semantic and pragmatic analyses of news headlines at different levels in Nigeria and beyond. For instance, MolekKozakowska (2014) explored the use of coercive metaphors in news headlines of a UK newspaper, using a cognitive-pragmatic technique while Dong and Shao (2016) did a pragmatic presupposition in English news headlines in China. Similarly, Al-Hindawi and Ali (2018) analysed headlines cast by CNN and BBC on civil unrest in Syria. Xie's (2018) analysed the intertextuality of English news headlines in China. Using the same pragmatic approach, Al-Saedi and Jabber (2020) analysed headlines 
in an Iraqi newspaper, while Rahman, Hossain, Islam, Chowdhury, Rafiq and Md. Badruzzaman (2019) had earlier analysed context-based news headlines in five major global newspapers with the help of Machine Learning. Other scholars worked on sentiment analyses (Bostan, Kim \& Klinger, 2019) and semantic analyses of news headlines (Chavan, 2018; Khan, Hassan, Hassan \& Ghanni Khan, 2018; Mohammed, Eid, Badawy \& Hassan, 2019). Specifically in Nigeria, studies in these areas concentrated on usage of prepositions in newspapers headlines (Ibrahim \& Yunus, 2017; Ibrahim, Haruna, Bashir \& Yunus, 2018), pragmasemantic silences (Nwala \& Umukuro, 2017) and ambiguity in news headlines (Chinelo \& Macpherson, 2015) as well as language use in news headlines (Robert, 2020).

However, there is a dearth of literature on the combination of pragmatics and lexico-semantics to analyse health-related news headlines (especially pandemic) in Nigeria. Two, existing studies have not established how health-related news headlines influence Nigerians' information-seeking behaviour, especially news about the COVID-19 pandemic. This study was, therefore, designed to fill these gaps by examining the lexical items that Nigerian newspaper editors selected to cast headlines of COVID-19related news stories. This was done to establish the pragma-semantic implications of the headlines for audience information-seeking behaviour and perception of the virus. Specifically, we set three questions to guide the study: (1) Between coronavirus and COVID-19, what name do news audience prefer to call the new virus? (2) How does the media presentation of the new virus in their headlines influence the name that the 
audience give to the virus? (3) What are the pragma-semantic implicatures of lexical items in newspaper headlines and their implications for the information-seeking behaviour of the audience? We employed Pragmatic Acts and Information-Seeking theories as the theoretical framework while we used the mixed-method design comprising online survey and content analysis as methods.

\section{LITERATURE REVIEW AND THEORETICAL FRAMEWORK}

\section{Headlines Construction and Implications for News Interpretation by Audience}

Journalists' roles in educating, informing and sensitising the public, and surveying the environment are vital to society, especially during health crises. One of the ways through which the journalists perform these functions is headline casting. Jiang, Xu, Wu and Guo (2020:2) submit that in casting news headlines about health, journalists adopt 'verbal techniques, selectivity and negativity' to attract the attention and influence the behaviour of their audiences. They also use positioning for driving attention in news headlines. The use of larger font sizes, which are connoted by kickers, is another strategy.

Good news headlines provide a succinct summary of news stories (Scacco \& Muddiman, 2019) with connotative and denotative functions (Prather \& Thadphoothon, 2017). When a headline is used denotatively, its meaning is direct and literal. On the other hand, connotative meanings of headlines are interpreted contextually based on the emotions or mental pictures associated with the headlines. To Scacco and Mudiman (2019), headlines 
are also used to generate readers' interest, satisfy their immediate information need and direct their attention to issues. Interpretatively, headlines are powerful storing-telling tools that influence the way and how readers think about an event, interpret it and act on it.

In journalism, different types of headlines are identified. Some of these include banner, crossline, flush, and kicker headlines (Sharma, 2017). Banner headlines grab readers' attention, and as such are cast in big type fonts. As the name implies, crossline headlines cover the entire width of a news page. Flush headlines consist of two or three unequal heads flushed left or right of a news story. Although there are arguments that a kicker is a strategy for headline casting, the fact remains that a kicker introduces the headline. Always the first word or phrase in a kicker headline can be written in capital letter, italics or underlining with a colon to attract readers' attention. In essence, anytime each of the headline types is used by the editor, certain behavioural responses are generated from the readers in terms of the attention such headline and the entire story get from the audience. The degree of believability with which the audience read and how they interpret the entire story may be determined, largely, by the nature of the headline the editor has used to drive the story. Therefore, because of their importance in how news stories are deconstructed, news headlines construction is always reserved for editors with more professional exposure and skills.

\section{News Media and Citizens' Health Behaviour in Health Crises}

In crises, people turn to different sources to seek information that may, partly or may not answer their information-seeking desires. Research has 
shown that in a health crisis like the COVID-19 pandemic, people seek more information about the pandemic from the Internet and the news media. This information-seeking behaviour, especially online, has become the trend in understanding health issues (Jiang, Xu, Wu \& Guo, 2020 and Nielsen, Fletcher, Newman, Brennen \& Howard, 2020). Because of the potential social impact of how an outbreak is reported, journalists are saddled with the responsibility of truthful, unbiased, ethical and accurate reporting, especially during health crises. Therefore, timely, accurate and non-sentimental reportage and clarifications in a pandemic reduce the uncontrolled, indiscriminate flow of information (UNESCO, 2020). However, because of novelty in emerging diseases (such as COVID-19) and the need to report them as being newsworthy, the media tend to conceptualise themes that create fear in people (Smith, et al., 2013).

In a study by Bento, Nguyen, Wing, Lozano-Rojas, Ahn and Simion (2020) for instance, the moment the first case of COVID-19 was recorded in the United States in January 2020, her citizens' search pattern showed that Coronavirus was used more as a search term. When recorded cases began to rise, searching for Coronavirus decreased. Instead, people started searching for terms such as Coronavirus symptoms and hand sanitiser. According to the researchers, announcements by relevant agencies increased the rate at which US citizens sought more information about the pandemic. A similar search pattern was established by Showkat and Gull (2020).

Also, the submission of Liu (2020) shows that the information-seeking behaviour of Chinese about COVID-19 as influenced by the news media 
was connected to health behaviour change. With the level of contents they consumed on different media platforms, the Chinese were able to adopt COVID-19 preventive measures. According to Liu's findings, his Chinese respondents' health behaviour was prevention-centric because their searches about the new virus heightened their anxiety. Following precautions reported by the media thereby became their priority (Showkat $\&$ Gull, 2020). Suffice to note that as journalists develop themes around certain words in health-related headlines, such themes come with inherent pragmatic acts (implicatures) that make news consumers interpret headlines differently in the pandemic-centric context.

\section{THEORETICAL FRAMEWORK}

Jacob Mey's (2001) Pragmatic Acts Theory and Information-Seeking Behaviour Theory are used as a framework for this study. Mey's Pragmatic Acts Theory is an extension of the Speech Act Theory by Austin [1962] as modified by Searle (1976). This is because the theory is Mey's attempt to remedy some inherent weaknesses of the Speech Acts Theory. According to Searle (1976), speaking (or writing) a language is performing a speech act. Therefore, to give commands, to make promises, to express feelings, or to ask questions is regarded as a speech act, which is made possible with specific rules for using the language. As Searle contends, speech acts are actions of speaking through which the source (speaker/or writer) presents their intention to the receiver. Whereas the classification by Austin is driven by performative verbs, Searle's classification is based on rules (Searle, 1979; Ogungbe, 2014). 
In response to the tenets of Speech Acts Theory by Austin (1962) as modified by Searle (1976), Mey (2001) posits that acts should not be attributed to speech as a speech by itself does not act. On the contrary, in the long run, utterances made (speech acting) and the meaning they suggest are a function of the situation (context) in which the speech acting occurs. Therefore, to realise any speech acts, such acts must be situated in an identifiable context. In essence, pragmatic acts are situated speech acts. This means that in pragmatic acts, communication (utterance/speech), context and meaning co-occur. It is this co-occurrence of these elements that define any pragmatic acts (functions) performed by a communicative situation. Instead of emphasizing performative verbs and rules as suggested by Austin (1962) and Searle (1976), respectively, pragmatic acts manifest in, and is conditioned by, a definite context (Odebunmi, 2006; Hoye \& Kaiser, 2007; Ogungbe, 2014). Pragmatic acts are allencompassing as they embrace the whole communication activities: linguistics (lexis/semantics, syntax, and phonology), and non-verbal communication (body language and visual images) in the communication context (Mey, 2001; Ogungbe, 2014).

In Mey's Pragmatic Acts, there is a higher rank of discourse called Pragmeme, which has "activity"e and "textual"e components. The "activity" component specifies the roles of the participants of the discourse also called interactants, while the "textual" component refers to the various contextual variables that exist and interact in discourse situations. Pragmatic Acts Theory pays attention to the environmental variables that determine what the discourse participants (interactants) can say, what they are saying, and what they cannot say in communicative contexts. Mey 
explains that the interaction between "activity" and "textual" components produces what is called "ipra" ("pract") and "allopract". For instance, the "ipra"e (also known as "pract") starts a pragmatic act to realize a "pragmeme". In this process, each "practe is simultaneously a specific production of a definite pragmeme called "allopract" (Emike, 2015). A "pract" is the knowledge that the interactants have on a communicative subject and the effects of such an event on the discourse participants in that particular discourse situation. As the discourse participants interact in a discourse situation, they produce speech acts, conversational acts, physical acts, psychological acts and prosodic acts, all of which are realised in varied contexts: INF (inference); REF (reference); VCE (Voice); SSK (Shared Situation Knowledge); MPH (Metaphor); and M (Metapragmatic Joker) (Mey, 1962; Ogungbe, 2014; Emike, 2014). The metapragmatic joker refers to some signals or cues that enable the discourse participants to interpret and share meanings in a certain discourse situation. Indexical expressions are context-specific; they are expressions whose meanings can change as the discourse contexts change. Therefore, metapragmatic indexicality is the term that explains how pragmatic acts generate discourse, and how the discourse participants use the context to construe meanings, which could be explicit (clearly or plainly expressed) or implicit (inferred or indirect).

We consider Mey's (2001) Pragmatic Acts Theory relevant to this current study because the study focuses on how lexical items in the headlines of COVID-19 and Coronavirus stories in Nigerian newspapers are constructed and their pragmatic implications. The construction of the newspapers' headlines represents a discourse phenomenon that could 
perform some pragmatic acts in terms of the influence they are likely to have on the media audience. The lexical and semantic properties of Nigerian newspaper headlines, specifically in the context of COVID-19 pandemic reporting, could provide some context-specific metapragmatic indexicals with both explicit and implicit meanings. The pragmatic acts of such indexicals in the news headlines could be any of confirming, warning, convincing, educating, forecasting, castigating, sympathising, sensitizing, condemning, urging, commending, or recommending. When citizens interact with the headlines, the pragmatic acts of the metapragmatic indexicals in the headlines of Coronavirus or/and COVID-19-related news could have some influence on the citizens' knowledge of, and informationseeking behaviour about, the virus.

Similarly, the basic assumption of Information-Seeking Theory traced to Wilson's Model of Information Seeking Behaviour (1981) holds that people have information needs they require answers to, and while seeking answers, they approach communication infrastructure (media) available to them (whether formal or informal). Their source(s) of information can either be reliable or unreliable, thereby influence (s) their interpretation and adoption of the information retrieved.

Such needs according to Wilson include physiological, affective and cognitive needs of information seekers. The information they are seeking is regarded as resources, data and knowledge gathering in their environment. In what is described as a communication process, people become unsatisfied with their information needs if such information fails to answer their questions (Koja-Odongo \& Mostert, 2006). Also, this 
theory argues that information seekers become stressed up if accessing prompt and objective information and topical analyses becomes cumbersome. However, Wilson hypothesises that two forms of behaviour are exhibited in information-seeking behaviour: passive search and passive attention. In a passive search, people search for information unintentionally, but their information-seeking urge enables them to acquire new and relevant knowledge. The same thing happens in passive attention, but the only difference in passive attention is that individuals unconsciously acquire information by consuming media contents. In this study, we postulated that Nigerian newspapers with an online presence (aggregated by Google News because of their ability to generate unique and constant news reports to the Nigerian audience) become the sources where newsreaders get information about the new coronavirus. Besides, the lexical items selected by the news editors to cast the headlines would have some pragma-semantic influence on how Nigerians seek information about the COVID-19 pandemic.

\section{METHODS, DATA AND ANALYSES}

To account for the pragma-semantic implications of lexical items of news headlines for audience information-seeking behaviour and perception of COVID-19, we adopted the descriptive survey and content analysis. We relied on data generated from the news contents, real-time data and survey. Categorised and aggregated headlines of COVID-19-related news stories were the first source of data for the study while the real-time data from Google Trends (a search normalised tool from Google) and online survey were the second and third sources respectively. We used the propositions 
of Pragmatic Acts and Information-Seeking theories to construct the study instruments. We adopted the two terms (COVID-19 and coronavirus) to generate the primary categories (kicker, rider and blur) for each of the two keywords, respectively. This produced a six-category coding sheet (content categories) as the instrument for the content analysis. We defined a kicker as a headline that is prefixed with a word or two-word clause followed by a colon; a rider as a headline also with few word-count placed without a colon before adding more clause or phrase; and a blur as a headline with a keyword or term situated at the extreme (Dick, n.d).

For the survey, an online questionnaire for the news audience formulated and validated by authors through a face validity approach constituted the instrument. Nigerians (news audience) who participated in the study were selected through available and pooled sampling procedures. We employed these procedures because of the non-availability of a comprehensive and accurate national citizen database that could help in adopting probability sampling techniques. Besides, given the lockdown and enforcement of social distancing as a result of the COVID-19 pandemic at the time of collecting the data, the techniques were adopted as safer and the most costeffective (Caudill, 2010) means for reaching the citizens who participated in the study.

A total of 252 COVID-19 related news headlines were selected using the purposive sampling technique. From 27 February 2020 to 31 May 2020, news headlines that had coronavirus and COVID-19 as keywords or terms were selected using Google News, which normalised Nigerian newspapers' websites on the Internet. Microsoft Excel sheet was the main 
data collection tool for the extraction of real-time data from Google Trends. The tool was set to Nigeria region, study period's data and news category. The setting assisted the researchers in downloading public search interest in the two keywords/terms during the study period into a Microsoft Excel sheet. The interest ranged from 0 to 100, according to the Google Trends normalisation algorithm.

For the data generated through the survey, nominal and ordinal scales were used for measuring responses from 219 news audiences. A nominal measurement scale was used for measuring variables associated with the data (headlines) from the content analysis. Besides, to extract the possible metapragmatic indexicals in the news headlines, we used explicit pragmatic acts (such as convincing, sensitizing, warning, urging, educating, recommending, condemning, forecasting, confirming, and sympathising) to construct the analytical categories. Binary options (Yes as 2, and No as 1) were adopted for coding the categories formulated for headline and pragma-semantic analyses. For instance, when a category appeared in the content, we coded it as Yes using 2 as a value. When it did not occur in the content, we adopted No and used 1 as the value in the dataset.

Combined data from the two phases-real-time and survey-were analysed using descriptive statistics (Mean, Standard Deviation, and Range among others), discriminant analysis and multinomial logistic regression. Discriminant analysis was adopted because of the need to reveal which of the categories for the headline construction and pragmasemantic presentation of the issues and needs about the virus the audience 
Between Coronavirus and COVID-19: Influence of Nigerian Newspapers' Headline Construction on Audience Information-Seeking Behaviour

considered appropriate for understanding the disease while searching information on the Internet. Multinomial logistic regression was considered a suitable statistical approach because of the need to establish the category that significantly contributed to the audience understanding of the virus using the keywords (COVID-19 and coronavirus).

The inter-coder reliability test of the content categories was carried out using the absolute agreement criterion associated with Krippendorff's Alpha. Two coders independently coded 11 headlines sampled from the corpus. Four of the headline type categories were reliable absolutely (100), while two were within the moderate threshold (51-99). Two each of the pragmatics and semantics acts were reliable absolutely while 6 and 7 of semantics and pragmatics were reliable moderately respectively. One act each was also found to be within near moderate reliability threshold (2650) for the studied pragmatics and semantics acts. The results of the intercoder reliability test proved that the content categories were reliable.

\section{FINDINGS}

Findings show that journalists used both Coronavirus and COVID-19 as key operators in the news headlines. However, Coronavirus was used more than COVID-19 in the headlines to report the pandemic. In these two usages, the two terms appeared as kickers, blurs and riders. But Coronavirus as a kicker (first word or phrase separated by a colon in the headline) dominated the news headlines analysed. This had implications for the search behaviour of news audiences about the virus. The results are presented under three themes that represent the research questions set for the study. 
Between coronavirus and COVID-19: what name do the news audience prefer to call the virus?

Findings in Table 1 reveal that audience preferred COVID-19 to coronavirus as the search term while journalists used coronavirus than COVID-19 in headlines. The high Standard Deviation of 2.090 for coronavirus usage has established the higher intensity of using coronavirus than that of COVID-19 $(\mathrm{SD}=1.924)$ by the journalists. From the findings, the news audience appropriated COVID-19 $(\mathrm{M}=2.23$, $\mathrm{SD}=.810)$ than coronavirus $(\mathrm{M}=1.88, \mathrm{SD}=.783)$ while searching for the needed information about the virus.

Table 1. Descriptive Statistics for Aggregated Data of Use of Keywords by Journalists and Audience

\begin{tabular}{|l|l|l|l|l|}
\hline & $\begin{array}{l}\text { Journalist } \\
\text { s' use of } \\
\text { COVID- } \\
\mathbf{1 9}\end{array}$ & $\begin{array}{l}\text { Audience Degree } \\
\text { of using COVID- } \\
\mathbf{1 9} \text { while } \\
\text { searching }\end{array}$ & $\begin{array}{l}\text { Journalists' } \\
\text { use of } \\
\text { coronavirus }\end{array}$ & $\begin{array}{l}\text { Audience Degree } \\
\text { of using } \\
\text { coronavirus } \\
\text { while searching }\end{array}$ \\
\hline Mean & 3.30 & 2.23 & 3.30 & 1.88 \\
\hline $\begin{array}{l}\text { Std. } \\
\text { Deviation }\end{array}$ & 1.924 & .810 & 2.090 & .783 \\
\hline Minimum & 1 & 1 & 1 & 1 \\
\hline Maximum & 7 & 3 & 7 & 3 \\
\hline
\end{tabular}

Min (for Journalists) = During Coverage (1); (for Audience) $=$ Not Often (1) Max (for Journalists) = During Writing and Editing (7); (for Audience) = Very Often (3)

This result is made clearer with the findings presented in Table 2, where the audience reported that their exposure to the keywords in the headlines influenced them to use the keywords for information retrieval. From the 
findings as presented in Figure 1, Coronavirus was found to be used most (49.25\%) in March compared to other months in the news category of Google Trends. Over $42 \%$ of the audience indicated that they saw coronavirus in the headlines of the news they read during the month.

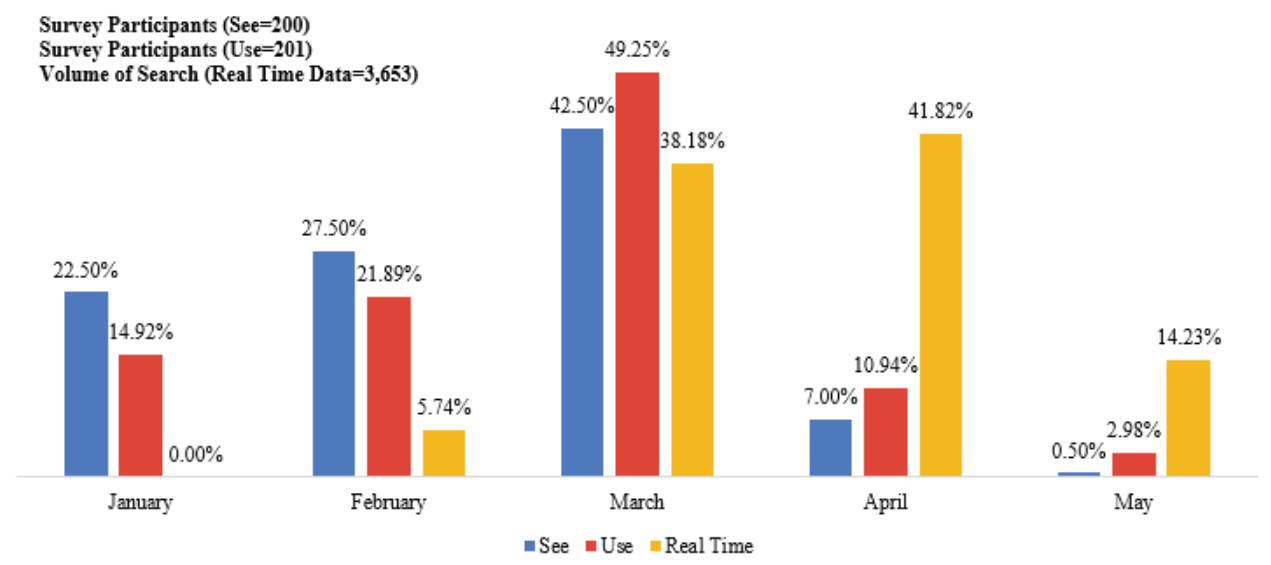

Figure 1. Frequency of Using Coronavirus as a keyword by audience per month

Despite that more than $49 \%$ of the audience used the keyword while searching for information about the virus, less than $40 \%(38.18 \%)$ of the volume of search occurred in the month. However, in April 2020, while over $41 \%$ of the volume of search occurred, less than $10 \%$ of the audience saw coronavirus but $10.94 \%$ used it as the keyword. 


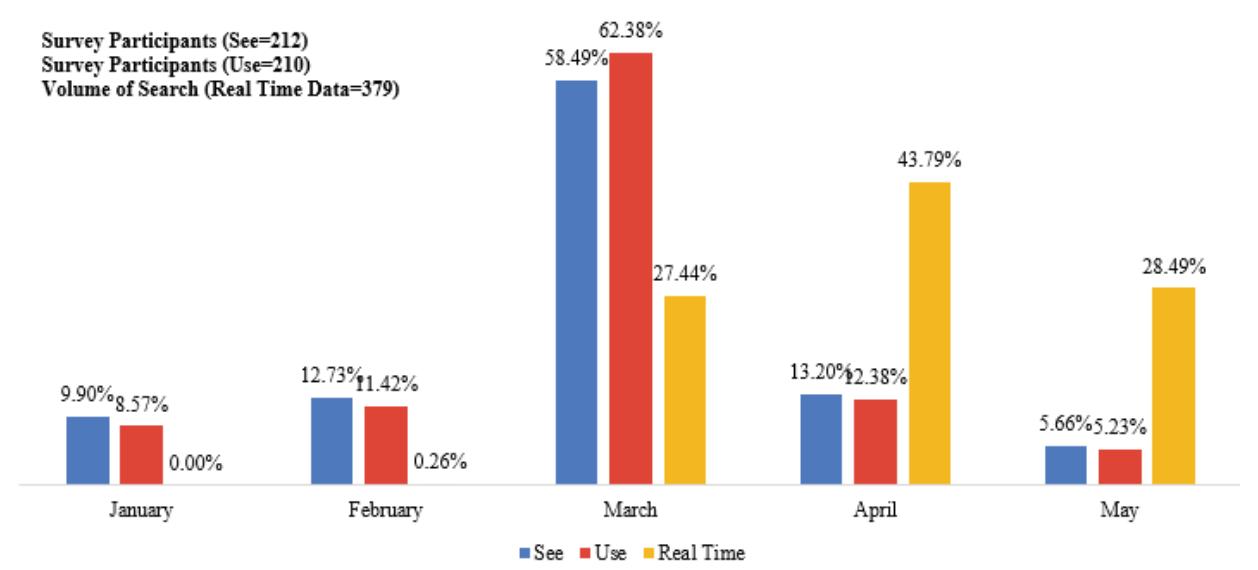

Figure 2. Frequency of Using COVID-19 as Keyword by audience per month

As presented in Figure 2, the use of COVID-19 to search information about the virus by the audience accounted for more than $60 \%$ compared to the use of Coronavirus (49.25\%) in the same month of March 2020 (See Figure 1). Over $58 \%$ of the participants also said they saw the keyword in the headlines of the news reported by the journalists. Surprisingly, the volume of search for the month was less than $30 \%$ (27.44\%) compared to more than $38.18 \%$ recorded for coronavirus. From the findings, it is also established that the volume of search about the virus using COVID-19 in April was higher (43.79\%) than what was obtainable when coronavirus was used $(41.82 \%)$. 
Table 2. Conclusion by Audience on How they Used Coronavirus/COVID-19 to Search for the Virus after Seeing the Terms in News Headlines

\begin{tabular}{|l|l|l|l|}
\hline \multirow{2}{*}{ Conclusion } & \multicolumn{2}{|c|}{$\begin{array}{c}\text { After seeing headlines, term or keyword } \\
\text { used for searching }\end{array}$} & \multirow{2}{*}{ Total } \\
\cline { 2 - 3 } & COVID-19 & $10(25.0 \%)$ & $\mathbf{4 0}(\mathbf{1 0 0 \% )})$ \\
\hline $\begin{array}{l}\text { The pandemic is called } \\
\text { COVID-19 }\end{array}$ & $\mathbf{3 0 ( 7 5 . 0 \% )}$ & $9(90.0 \%)$ & $10(100 \%)$ \\
\hline $\begin{array}{l}\text { The pandemic is called } \\
\text { coronavirus }\end{array}$ & $1(10.0 \%)$ & $\mathbf{6 4}(\mathbf{3 7 . 9 \% )}$ & $\begin{array}{l}\mathbf{1 6 9} \\
\mathbf{( 1 0 0 \% )}\end{array}$ \\
\hline $\begin{array}{l}\text { The pandemic is either } \\
\text { called coronavirus or } \\
\text { COVID-19 }\end{array}$ & $\mathbf{1 0 5 ( 6 2 . 1 \% )}$ & & \\
\hline
\end{tabular}

Findings in Table 2 reveal that participants were divided on whether the virus is COVID-19 or coronavirus. More than $62 \%$ of 169 participants believed that the virus is called coronavirus or COVID-19, but sought information about the virus using COVID-19, while $37.9 \%$ of the same participants were of the same view, but used coronavirus as a search term. Over $70 \%$ of 40 participants who believed that the virus is called COVID19 also used COVID-19 as a term or keyword while searching for information about the virus. 
Media Presentation of COVID-19 in the News Headlines and Public Discriminant of the Virus Search through the Internet

Table 3. Results of Wilks' Lambda Analysis of Association between Headline Types and Audience Search Interest Volume

\begin{tabular}{|l|l|l|l|l|}
\hline Test of Function(s) & $\begin{array}{l}\text { Wilks' } \\
\text { Lambda }\end{array}$ & Chi-square & df & Sig \\
\hline $\begin{array}{l}\text { Coronavirus as kicker through } \\
\text { coronavirus as blur }\end{array}$ & .119 & 189.447 & 174 & .200 \\
\hline $\begin{array}{l}\text { Coronavirus as rider through } \\
\text { coronavirus as blur }\end{array}$ & .288 & 110.901 & 114 & .565 \\
\hline $\begin{array}{l}\text { Coronavirus as blur } \\
\begin{array}{l}\text { COVID-19 as kicker through COVID- } \\
19 \text { as rider }\end{array}\end{array}$ & $\mathbf{. 6 3 3 0}$ & $\mathbf{4 0 . 6 8 5}$ & $\mathbf{5 6}$ & $\mathbf{. 9 3 8}$ \\
\hline COVID-19 as rider & $\mathbf{. 9 6 5}$ & $\mathbf{2 . 6 0 4}$ & $\mathbf{2 0}$ & $\mathbf{. 3 3 4}$ \\
\hline
\end{tabular}

Table 3 presents the results of Wilks' Lambda analysis that establish an association between headline types and audience search interest volume during the studied period. Five functions were explored using kicker, rider and blur headline types as exemplified earlier. Contrary to our expectation, we did not find a significant association between the two variables. However, we found more than $50 \%$ variation of coronavirus as a blur in audience volume of search interest about the virus (Wilks' Lambda $=.633$, Chi-square $=22.114, \mathrm{P}>.334$ ), of COVID-19 as kicker through COVID-19 as a rider (Wilks' Lambda $=.740$, Chi-square $=40.685$, $\mathrm{P}>.938$ ), and of COVID-19 as a rider (Wilks' Lambda $=.965$, Chi-square $=2.604, \mathrm{P}>$.978). These variations can be explained by the degree of freedom. For instance, the variation of coronavirus as a blur is linked with the search interest 56 score threshold. The variation level of COVID-19 as 
a kicker through COVID-19 as a rider picked when the interest is at the 20 score threshold. COVID-19 as a rider had the lowest search interest score threshold $(\mathrm{n}=9)$. These results imply that coronavirus as a blur is much better than COVID-19 as a kicker through COVID-19 as a rider and COVID-19 as a rider in influencing audience information seeking about the virus within the context of search interest threshold. However, COVID-19 as a kicker through COVID-19 as a rider and COVID-19 as a rider is better in terms of variation of the headlines in total search interest volume. Both data patterns are explicated further in Table 4.

Table 4. Tests of Equality of Group Means

\begin{tabular}{|l|l|l|l|l|l|}
\hline & Wilks' Lambda & F & df1 & df2 & Sig. \\
\hline Coronavirus as kicker & .485 & 1.134 & 58 & 62 & .313 \\
\hline Coronavirus as rider & $\mathbf{. 6 0 0}$ & .713 & 58 & 62 & .902 \\
\hline Coronavirus as blur & .454 & 1.283 & 58 & 62 & .167 \\
\hline COVID-19 as kicker & $\mathbf{. 7 7 4}$ & $\mathbf{2 . 0 5 0}$ & $\mathbf{1 0}$ & $\mathbf{7 0}$ & $\mathbf{. 0 4 1}$ \\
\hline COVID-19 as rider & - & - & - & - & - \\
\hline COVID-19 as blur & $\mathbf{. 9 4 6}$ & .397 & 10 & 70 & .944 \\
\hline
\end{tabular}

Based on the data presented in Table 4, it could be inferred that COVID19 as a kicker significantly contributed to audience information search interest about the virus (Wilks' Lambda=.774, $\mathrm{F}=2.050, \mathrm{P}<.041$ ) than other headline types. The data also establish that COVID-19 as blur (Wilks' Lambda $=.946$ ) and coronavirus as a rider (Wilks' Lambda=.600) 
had better variation than coronavirus as a kicker (Wilks' Lambda=.485) and coronavirus as a blur (Wilks' Lambda $=.454$ ). These results imply that when COVID-19 was used as a kicker, it enhanced audience search interest more than when used as rider and blur.

Table 5. Classification Coefficients

\begin{tabular}{|l|l|l|l|}
\hline $\begin{array}{l}\text { Select Search Interest } \\
\text { Score Range }\end{array}$ & $\begin{array}{l}\text { Coronavirus as } \\
\text { kicker }\end{array}$ & $\begin{array}{l}\text { Coronavirus as } \\
\text { rider }\end{array}$ & $\begin{array}{l}\text { Coronavirus as } \\
\text { blur }\end{array}$ \\
\hline 2 & $\mathbf{3 1 . 9 1 9}$ & $\mathbf{7 3 . 7 6 7}$ & 28.515 \\
\hline 34 & $\mathbf{3 0 . 6 2 8}$ & $\mathbf{5 1 . 7 4 7}$ & 29.444 \\
\hline 65 & 29.764 & $\mathbf{5 1 . 4 4 3}$ & 30.066 \\
\hline 100 & 29.764 & $\mathbf{5 1 . 4 4 3}$ & 30.666 \\
\hline $\begin{array}{l}\text { Select Search Interest } \\
\text { Score Range }\end{array}$ & $\begin{array}{l}\text { COVID-19 as } \\
\text { kicker }\end{array}$ & $\begin{array}{l}\text { COVID-19 as } \\
\text { rider }\end{array}$ & $\begin{array}{l}\text { COVID-19 as } \\
\text { blur }\end{array}$ \\
\hline 1 & 8.634 & - & $\mathbf{1 4 . 1 6 6}$ \\
\hline 4 & $\mathbf{1 0 . 9 9 2}$ & - & $\mathbf{1 4 . 3 9 9}$ \\
\hline 8 & $\mathbf{1 3 . 8 7 4}$ & - & $\mathbf{1 4 . 6 8 3}$ \\
\hline 11 & 8.634 & - & $\mathbf{1 4 . 1 6 6}$ \\
\hline
\end{tabular}

Fisher's Discrimination Function

From the use of coronavirus for COVID-19 as the keyword in the headlines, findings presented in Table 5 indicate that coronavirus as a rider increased search interest more than being used as kicker and blur. As the findings show, coronavirus as rider increased search interest by $73.7 \%$ when the search interest reached two scores out of the expected 100 score threshold. Over 51\% increase was recorded when the search interest reached 34, 65 and 100 score. However, there is no significant difference 
in percentage contribution of coronavirus as a rider to search interest score when coronavirus was used as a kicker, rider and blur when the search interest score range was at 65 and 100. The findings in Table 5 also reveal that COVID-19 as a kicker, rider and blur contributed less to search interest score. In line with the data, one can infer that COVID-19 usage in the select news headlines increased search interest by less than $15 \%$. There are several possible explanations for these results. One of the explanations is that the dominant use of coronavirus in the early coverage of the virus could be adduced for the significant contribution of coronavirus as kicker, rider and blur had on the search interest score. To further understand this, we carried out a structure matrix analysis using three function scenarios. This is imperative because of the need to see how the headline type linked with the search interest volume and expose the appropriate type that contributed to the information seeking of the audience.

\begin{tabular}{|l|l|l|l|}
\hline \multirow{2}{*}{} & \multicolumn{3}{|c|}{ Function } \\
\cline { 2 - 4 } & $\mathbf{1}$ & $\mathbf{2}$ & $\mathbf{3}$ \\
\hline Coronavirus as kicker & -.007 & $.999^{*}$ & -.031 \\
\hline Coronavirus as rider & .558 & $-.596^{*}$ & -.578 \\
\hline Coronavirus as blur & .300 & -.142 & $.943^{*}$ \\
\hline COVID-19 as kicker & $.979^{*}$ & .205 & - \\
\hline COVID-19 as rider & - & - & - \\
\hline COVID-19 as blur & -.279 & $.961^{*}$ & - \\
\hline
\end{tabular}

Table 6. Structure Matrix

*Largest absolute correlation between each variable and any discriminant function As shown in Table 6, one unit of coronavirus as a kicker in the headlines increased audience search interest by $99.9 \%\left(r^{2}=.99 .9\right)$. This is equally 
attained for COVID-19 as blur, but the percentage increase was 96.1\% $\left(\mathrm{r}^{2}=.961\right)$. Coronavirus as blur performed better in the third function $\left(r^{2}=.943\right)$ than the first function $\left(r^{2}=.300\right)$ and second function $\left(r^{2}=-.142\right)$. In the second function, coronavirus as rider correlated with the search interest negatively $\left(\mathrm{r}^{2}=-.596\right)$, while it had a positive connection in the first function $\left(\mathrm{r}^{2}=.558\right)$. This implies that when one unit of using coronavirus as rider increases search interest by $55.8 \%$, it reduces the interest by $59.6 \%$ when it was used as a rider too. Meanwhile, COVID-19 as a kicker performed better in the first function $\left(\mathrm{r}^{2}=.979\right)$. Following the same interpretation pattern, the result suggests that one unit of appropriating COVID-19 as a kicker increases search interest by $97.9 \%$. In general, it seems that journalists and audiences did not always have specific keywords/terms while reporting the virus and seeking knowledge about it. Therefore, both the journalists and audience discriminated while employing the keywords. Since they discriminated, we further explored the place of pragma-semantic presentation of the headlines by the journalists in audience information seeking about the virus.

\section{Influence of Pragma-Semantic Interpretations of Newspapers' Headlines on Audience Information-Seeking Behaviour}

From the findings in Table 7, it is clear that the audience understood the headlines within sensitising (Chi-square $=37.853, \mathrm{df}=11, \mathrm{P}<.000$ ), warning $($ Chi-square $=31.460, \mathrm{df}=11, \mathrm{P}<.001)$ and confirming $($ Chi-square $=30.549, \mathrm{df}=11, \mathrm{P}<.001)$ features than educating and assessing before searching for additional information about the virus using COVID-19 as a term/keyword. The findings also suggest that when coronavirus was used 
as a keyword, the audience earlier understood the headlines within confirming $($ Chi-square $=79.086, \mathrm{df}=58, \mathrm{P}<.034)$ and warning $(\mathrm{Chi}-$ square $=78.320, \mathrm{df}=58, \mathrm{P}<.039$ ) pragmatic features.

Table 7. Likelihood Ratio Tests of Select Pragmatics Presentation in the Headlines on Public Volume of Search

\begin{tabular}{|c|c|c|c|c|}
\hline \multirow[t]{2}{*}{ Effect } & Model Fitting Criteria & \multicolumn{3}{|c|}{ Likelihood Ratio Tests } \\
\hline & $\begin{array}{c}\text {-2 Log Likelihood of Reduced } \\
\text { Model }\end{array}$ & Chi-Square & Df & Sig. \\
\hline Intercepting & 144.944 & .000 & 0 & - \\
\hline Educating & 153.703 & 8.759 & 11 & .644 \\
\hline Warning & 176.404 & 31.460 & 11 & .001 \\
\hline Sensitising & 182.797 & 37.853 & 11 & .000 \\
\hline Assessing & 160.105 & 15.161 & 11 & .175 \\
\hline Confirming & 175.493 & 30.549 & 11 & .001 \\
\hline coronavirus & & & & \\
\hline Intercepting & 225.383 & .000 & 0 & - \\
\hline Educating & 292.601 & 67.218 & 58 & .191 \\
\hline Warning & 303.703 & 78.320 & 58 & .039 \\
\hline Sensitising & 294.059 & 68.676 & 58 & .159 \\
\hline Assessing & 275.918 & 50.535 & 58 & .746 \\
\hline Confirming & 304.469 & 79.086 & 58 & .034 \\
\hline
\end{tabular}

The findings in Table 7 are similar to those presented in Table 8. The significant difference only lies with the fact that the data in Table 7 focus 
on the likelihood ratio of occurrence of semantics features in the headlines and interpretation by the audience before seeking information about the virus.

Table 8. Likelihood Ratio Tests of Select Semantics Presentation in the Headlines on Public Volume of Search

\begin{tabular}{|c|c|c|c|c|}
\hline \multirow{3}{*}{$\begin{array}{l}\text { Effect } \\
\text { COVID-19 }\end{array}$} & \multirow{3}{*}{$\begin{array}{c}\text { Model Fitting Criteria } \\
-2 \text { Log Likelihood of } \\
\text { Reduced Model }\end{array}$} & \multicolumn{3}{|c|}{ Likelihood Ratio Tests } \\
\hline & & \multirow[t]{2}{*}{ Chi-Square } & \multirow[t]{2}{*}{ Df } & \multirow[t]{2}{*}{ Sig. } \\
\hline & & & & \\
\hline Intercepting & 127.169 & .000 & 0 & \\
\hline Educating & 164.783 & 37.615 & 11 & .000 \\
\hline Warning & 153.322 & 26.153 & 11 & .006 \\
\hline Sensitising & 151.431 & 24.262 & 11 & .012 \\
\hline Assessing & 151.519 & 24.350 & 11 & .011 \\
\hline Confirming & 134.363 & 7.194 & 11 & .783 \\
\hline \multicolumn{5}{|l|}{ coronavirus } \\
\hline Intercepting & 777.617 & .000 & 0 & \\
\hline Educating & 1015.633 & 238.016 & 58 & .000 \\
\hline Warning & 563.942 & . & 58 & . \\
\hline Sensitising & 267.095 & & 58 & \\
\hline Assessing & 540.194 & & 58 & \\
\hline Confirming & 661.533 & . & 58 & . \\
\hline
\end{tabular}

As presented in Table 8, the findings show that the use of COVID-19 in the headlines to educate (Chi-square $=37.615, \mathrm{df}=11, \mathrm{P}<.000$ ), warn (Chi- 
square $=26.153, \mathrm{df}=11, \mathrm{P}<.006)$, assess $($ Chi-square $=24.350, \mathrm{df}=11$, $\mathrm{P}<.011$ ) and sensitise (Chi-square $=24.262, \mathrm{df}=11, \mathrm{P}<.012$ ) enhanced audience interest in seeking information about the virus than coronavirus as a keyword in the select headlines. Educating (Chi-square $=238.016$, $\mathrm{df}=58, \mathrm{P}<.000)$ as a semantic feature only aided audience information search when coronavirus was used as a keyword.

\section{DISCUSSION OF FINDINGS}

The study has established some level of divergence in journalists' and audiences' use of COVID-19 and coronavirus as a name for the pandemic. Despite the declaration of the disease as a pandemic several days before Nigeria reported her first index case, Nigerian newspapers, as manifested in the analysed COVID-19-related news headlines, failed to use COVID19 significantly as a lexical choice while stressing the severity of the virus. Instead, they used coronavirus more prominently. From the pragmasemantic perspective, it could be inferred that the journalists used coronavirus more often because they wanted the public to know about the virus rather than warn them about its severity or create panic about the disease. The behaviour exhibited by the Nigerian journalists in this instance seems to contradict what some previous studies have established. For instance, Smith et al. (2013) found that when an event is a novel, the media do create fear in people and conceptualise themes that resonate with the public mood to establish the significance of the event. However, the audience, as exemplified by the survey participants, exhibited a contrary behaviour by using COVID-19 more than coronavirus to seek the needed information about the virus. Although some participants claimed that they 
used COVID-19 more than coronavirus for information seeking, the findings reveal a high volume of search online for coronavirus. This further reinforces the finding that shows that audiences were divided on whether the virus is COVID-19 or coronavirus. This could be attributed to the use of the two terms or keywords erratically by the newspapers.

This information-seeking behaviour by Nigerian citizens is similar to what has been captured in the previous studies and supported by the propositions and assumptions of the theories that guide the current study. For example, Showkat and Gull (2020) have found that coronavirus and COVID-19 were among the most used keywords by people globally in the early wave of disease transmission to understand and gain more knowledge about the virus through Google News.

The current study has also established that while the use of COVID-19 as a kicker significantly contributed to audience information search interest than other headline types, coronavirus as a rider increased search interest more than being used as kicker and blur. But discriminate scenario analysis suggests that COVID-19 as kicker performed better in the first scenario than other categories of headlines. Also, the study has shown that using COVID-19 as a pragmatic feature with inherent implicit meanings in news headlines to report the virus could better aid audience interpretation within the indexicals of educating, warning, assessing and sensitising and eventual information seeking than using coronavirus. Educating as a semantic feature (with explicit meaning) only aided audience information search when coronavirus was used. 
The foregoing findings are in consonance with several existing studies, scholarly views and propositions of the theories adopted for the study. Jiang et al. (2020) have asserted that journalists could be selective and negative in their quest of attracting and influencing the public on important health issues and needs with the adoption of kickers. The use of COVID19 in the news headlines has also reinforced the fact that journalists believe in facilitating audience clicking, reading and using news reports for further information needs for immediate benefits (Pan \& Meng, 2016; Jiang, et al., 2020; Scacco \& Muddiman, 2019). With the results that indicate that the lexical items in news headlines educate, warn, sensitise and assess within pragma-semantic features, our findings align with previous findings of some scholars (e.g. Ismail, 2016; Al-Saedi \& Jabber, 2020) that established expressives and assertives as the pragmatic attachments newspapers had in their headlines and that pragma-semantic features play knowledge storage and information interpretation roles in the mind of the audience about the reported phenomenon.

In summary, the results of our current study align with the Speech Acts and Information-seeking theories. Words are used and interpreted by discourse participants based on the prevailing phenomenon in the discourse context (Mey, 2001, Odebunmi, 2006; Ogungbe, 2014). As established by our study, Nigerian journalists' lexical choices to construct social, environmental and political realities around the COVID-19 pandemic have established the power of news media to determine topic of discourse that could equip the public with the needed information (Searle, 1979; Koja-Odongo \& Mostert, 2006). The Pragmatic Acts and Information-seeking theories have collectively provided the framework to 
justify the fact that the audience can construe both the explicit and implicit meanings of lexical items used by journalists to construct the pandemic. The terms or keywords used by journalists to construct headlines while reporting the COVID-19 pandemic could also influence audience behaviours while seeking the required information about the virus.

\section{CONCLUSION AND RECOMMENDATIONS}

Nigerian journalists use coronavirus and COVID-19 inconsistently as the main keywords in the headlines of news reports. There is a discrepancy in how the journalists and the audience use the two keywords: While the Nigerian journalists use coronavirus more frequently in news headlines to describe the virus, the audience use COVID-19 more often to search for information about the pandemic. Despite this apparent divergence in their usage, the terms, as deployed in news headlines, have some pragmasemantic implicatures such as warning, sensitizing, assessing, and educating, which could equip the audience with some level of knowledge while searching for information about the virus online. Through lexical choices by Nigerian journalists to construct social, environmental and political realities around the COVID-19 pandemic, the news media have determined the topics of discourse and conditioned the cognition of the media audience in Nigeria about the pandemic.

The evidence from this study suggests that Nigerian newspapers need to be consistent in using the keywords in their subsequent news reports about the virus and other health issues. Further studies with a focus on stylopragmatic analyses of COVID-19-related news and exploration of audience information-seeking behaviours using the two key terms are, 
therefore, suggested to establish direct relationships between the style of constructing news stories about the pandemic and audience knowledge, belief and attitudes.

\section{REFERENCES}

[1.] Al-Hindawi, F.H. \& Ali, A.H. (2018). A Pragmatic Study of CNN and BBC News Headlines Covering the Syrian Conflict. Advances in Languages and Literary Studies 9 http://dx.doi.org/10.7575/aiac.alls.v.9n.3p.43.

[2.] Austin, J. (1962). How to Do Things with Words. Cambridge: Harvard University Press.

[3.]Al-Saedi, H.T. and Jabber, K.W. (2020). A Pragmatic Study of Newspaper Headlines in Media Discourse: Iraq as a Case Study. International Journal of Linguistics, Literature and Translation 3(3), pp. 48-59.

[4.] Al-Jazeera (2020) Coronavirus: All you need to know in under 500 words. https://www.aljazeera.com/news/2020/01/china-coronavirus500-words-200127065154334.html

[5.]Berkeley, J. (2020). World Health Organization names the new coronavirus: COVID-19.'https://www.cnbc.com/2020/02/11/worldhealth-organization-names-the-new-coronavirus-COVID-19.html

[6.] Bhowmik, S., Rony, M.M., Haque, M.M., Swain, K.A. \& Hassan, N. (2019). Examining the Role of Clickbait Headlines to Engage Readers with Reliable Health-related Information. arXiv preprint arXiv:1911.11214.

[7.]Bostan, L., Kim, E., and Klinger, R. (2019). Good News Everyone: A Corpus of News Headlines Annotated with Emotions, Semantic Roles, and Reader Perception. arXiv preprint arXiv:1912.03184.

[8.]Bento, A. I., Nguyen, T., Wing, C., Lozano-Rojas, F., Ahn, Y.Y. \& Simon, K. (2020). Evidence from Internet Search Data Shows Information-Seeking Responses to News of Local COVID-19 Cases. Proceedings of the National Academy of Sciences, 117(21), pp. 11220-11222.

[9.] Chavan, S.S. (2018). Sentiment Classification of News Headlines on India in the US Newspaper: Semantic Orientation Approach vs 
Machine Learning. A PhD dissertation, Dublin, National College of Ireland.

[10.] Caudill, S.P. (2010). Characterizing Populations of Individuals Using Pooled Samples. Journal of Exposure Science \& Environmental Epidemiology 20, pp. 29-37. https://doi.org/10.1038/jes.2008.72.

[11.] Colvin, K. (2020). The people versus COVID-19. European Medical Journal 5(1), pp. 20-23.

[12.] Chinelo, J.E. \& Macpherson, N.A. (2015). A Stylistic Exploration of Lexical Ambiguity in Newspaper Headlines." Humanity and Social Sciences Journal 10(2), pp. 63-72.

[13.] Charlse, M.K. (2019). Newspaper Framing of a Health Crisis and Public Perception in Kenya: The Case of Kenyatta National Hospital Wrong-Patient Brain Surgery. An MA Thesis at School of Communication, Cinematics and Creative Arts. URI: http://erepo.usiu.ac.ke/11732/5008.

[14.] Dong, M. \& Zheng, J. (2020). Letter to the editor: Headline stress disorder caused by Netnews during the outbreak of COVID-19. Health Expectations 23, pp. 259-260. 10.1111/hex.13055.

[15.] Dong, T. \& Shao, P. (2016). The Analysis of Pragmatic Presupposition in English News Headlines. 2nd International Symposium on Social Science. Atlantis Press.

[16.] Dick, M. (n.d.). Search Engine Optimisation in UK News Production.

https://bura.brunel.ac.uk/bitstream/2438/8348/2/Fulltext.pdf

[17.] Emike A.J. (2015). The Pragma-Crafting Theory: A Proposed Theoretical Framework for Pragmatic Analysis. American Research Journal of English and Literature, 1(2), pp. 21-32.

[18.] Guarner, M.D. (2020). Three Emerging Coronaviruses in Two Decades: The Story of SARS, MERS, and Now COVID-19. American Journal of Clinical Pathology 153 (4), pp. 420-421.

[19.] Ibrahim, B. \& Yunus, K. (2017). The Usage of Spatial Prepositions for Political Aspirations in the Headlines of the Nigerian Newspapers. International Journal of English Linguistics 7(6), pp. 246-254.

[20.] Ibrahim, B., Haruna, H.H., Bashir, I. \& Yunus, K. (2018). The Usage of Spatial Prepositions in the Headlines of Major Nigerian Newspapers. International Journal of English Linguistics 8(7), pp. 1322. 
[21.] Jiang, T., Xu, Y.\& Wu, X. (2020). The Effects of Evidence Type on Online Health Headline Selection-A Moderation of Thinking Style. iConference 2020 Proceedings.

[22.] Koja-Odongo, R. \& Mostert, J. (2006). Information Seeking Behaviour: A Conceptual Framework. South African Journal of Libraries and Information Science 72. 10.7553/72-3-1112.

[23.] Khan, M. Z., Hassan, M. A., Hassan, S.U. \& Ghanni Khan, M.U. (2018). Semantic Analysis of News Based on the Deep Convolution Neural Network. 14th International Conference on Emerging Technologies, Islamabad, pp. 1-6. Doi: 10.1109/ICET.2018.8603653. [24.] Liu, P.L. (2020). COVID-19 Information Seeking on Digital Media and Preventive Behaviors: The Mediation Role of Worry. Cyberpsychology, Behavior, and Social Networking, 23 (10), рp. 1-6.

[25.] Laidlaw, T. (2019). Pandemic Stories: Rhetorical Motifs in Journalists' Coverage. Minerva 57, 433-451. https://doi.org/10.1007/s11024-019-09383-4

[26.] Mohammed, P., Eid, Y., Badawy, M. \& Hassan, A. (2019). Evaluation of Different Sarcasm Detection Models for Arabic News Headlines. International Conference on Advanced Intelligent Systems and Informatics, pp. 418-426.

[27.] Molek-Kozakowska, K. (2014). Coercive Metaphors in News Headlines: A Cognitive-Pragmatic Approach. Brno studies in English 40(1).

[28.] Mey, J. (2001). An Introduction to Pragmatics. Oxford: Blackwell Publishing.

[29.] Nielsen, R.K., Fletcher, R., Newman, N., Brennen, S.J. \& Howard, P.N. (2020). Navigating the 'infodemic': How people in six countries access and rate news and information about coronavirus. Reuters Institute.

[30.] Nwala, M.A. \& Umukoro, B.A. (2017). Investigating the Meaning of Newspaper Headlines: The Issue of Ambiguity. African Research Review 11(3), pp. 87-96. 
[31.] Odebunmi, A. (2006). A Pragmatic Reading of Ahmed Yerima's Proverbs. In Yemoja, Attahiru, and Dry Leaves on Ukan Trees. Intercultural Pragmatics 3.2, pp. 153-169.

[32.] Ogungbe, E.O. (2014). A Critical-Pragmatic Approach to Reading Photo News in Nigerian Newspapers. Journal of Language and Communication Art 6. A Publication of the Department of Communication and Language Arts, University of Ibadan.

[33.] Ojebuyi, B.R. and Lasisi, M.I. (2019). Speaking Up or Staying Silent? Citizens' Engagement of Pro-Biafra Protests and FarmersHerders Crises in the User generated Content of Selected Nigerian Online Newspapers,'Ethiopian Journal of the Social Sciences and Humanities 15 (2), pp. 25-51. https://www.ajol.info/index.php/ejossah/article/view/194567.

[34.] Ojebuyi, B.R. (2016). Negative Rhetoric in the User-generated Content of Nigerian News Media. Journal of Communication and Language Arts, 7(1), pp. 85-106.

[35.] Prather, E. \& Thadphoothon, J. (2018). A Discourse Analysis of Newspaper Headlines Containing the Words 'China' or 'Chinese': A Case Study of Two English Language Newspapers in Thailand. Communication and Culture for a Sustainable Society, 46.

[36.] Rahman, S., Hossain, S.S., Islam, S., Chowdhury, M.I., Rafiq, F.B. \& Md. Badruzzaman, K. (2019). Context-Based News Headlines Analysis Using Machine Learning Approach' In Nguyen N., Chbeir R., Exposito E., Aniorté P., Trawiński B. (eds). Computational Collective Intelligence. Vol 11684. Cham: Springer.

[37.] Robert, E. (2020). Language Use in Selected Newspaper Headlines. Journal of Arts and Humanities, 9(1), pp. 91-103.

[38.] Showkat, N. \& Gull, M. (2020). The Study of Google Search Trends for an Effective Communication during COVID-19 Pandemic. Sage Submissions

Preprint.

https://doi.org/10.31124/advance.12138732.v1.

[39.] Smith,K.C., Rimal, R.N., Sandberg, H., Storey, J.D., Lagasse, L., Rhoades, E.,Barnett, D.J., Omer, S.B. \& Links, J.M. (2013). Understanding Newsworthiness of an Emerging Pandemic: 
International Newspaper Coverage of the H1N1 Outbreak. Influenza Other Respir Viruses7(5), pp. 847-853.

[40.] Searle, J.R. (1976). The Classification of Illocutionary Acts. Language in Society 8, pp. 135-151.

[41.] Scacco, J.M. \& Muddiman, A. (2019). The Current State of News Headlines. https://mediaengagement.org/wpcontent/uploads/2019/05/the-current-state-of-news-headlines.pdf [42.] Sharma, A. (2017). News, Types of News, Types of Headlines.' https://www.slideshare.net/Arpita615/news-types-of-news-types-ofheadlines

[43.] UNESCO (2020). World Trends in Freedom of Expression and Media Development: Journalism, Press Freedom and COVID-19. France.

[44.] WHO (2020). Naming the coronavirus disease (COVID-19) and the virus that causes it. https://www.who.int/emergencies/diseases/novel-coronavirus2019/technical-guidance/naming-the-coronavirus-disease-(covid2019)-and-the-virus-that-causes-it

[45.] Worldometer (2021). COVID-19 Coronavirus Pandemic. https://www.worldometers.info/coronavirus/https://www.worldomete rs.info/coronavirus/

[46.] Ward, J. K. (2020). Journalists and Science 2: diversity in the media coverage of the 2009 pandemic flu vaccine's safety in France. https://doi.org/10.31235/osf.io/75tnh

[47.] Xie, Q. (2018). Analysis of Intertextuality in English News Headlines. Theory and Practice in Language Studies 8 (8). http://dx.doi.org/10.17507/tpls.0808.13 